\title{
FAKTOR MATERNAL YANG BERHUBUNGAN DENGAN KEJADIAN KURANG ENERGI KRONIS (KEK) PADA IBU HAMIL DI DAERAH URBAN
}

\author{
Nen Sastri ${ }^{\star}$ \\ *Program Studi Kebidanan STIK Bina Husada, JI. Syech Abdul Somad No.28 Kel.22 llir \\ Palembang Sumatera Selatan-30131 \\ Korespondensi Email: nensastri@yahoo.com
}

\begin{abstract}
ABSTRAK
Pendahuluan: Profil kesehatan Indonesian tahun 2015 menunjukkan bahwa AKI adalah sebesar 305 kematian ibu per 100.000 kelahiran hidup. Komplikasi yang terjadi tentunya tidak terlepas dari buruknya status gizi ibu dan pada akhirnya berdampak kepada kondisi janin yang dilahirkan. Metode: Penelitian yang digunakan adalah penelitian observasional dengan pendekatan case control. Populasi dalam penelitian ini adalah semua ibu hamil pada bulan 1 sd 12, tahun 2017. Kriteria Kasus adalah semua tersangka ibu hamil dengan KEK yang tercatat dalam buku I kehamilan dan pemeriksaan LILA diketahui kurang dari $23,5 \mathrm{~cm}$. Analisa data: analisis univariat, analisis bivariat, analisa Multivariat. Hasil: ibu hamil didapatkan distribusi frekuensi berdasarkan kejadian KEK sebanyak 87 kasus KEK. Hasil analisis hubungan antara umur dengan kejadian KEK diperoleh nilai signifikan $p=0,007$ OR diperoleh sebesar 3,302. Analisis hubungan antara pendidikan dengan kejadian KEK diperoleh nilai signifikan $p=0,030$ OR diperoleh sebesar 1,870. Analisis hubungan antara pekerjaan dengan kejadian KEK diperoleh nilai signifikan $p=0,002$ OR diperoleh sebesar 2,538. Analisis hubungan antara paritas dengan kejadian KEK diperoleh nilai signifikan $p=0,000$ OR diperoleh sebesar 2,758. Analisis hubungan antara jarak kelahiran dengan kejadian KEK diperoleh nilai signifikan $p=0,014$ OR diperoleh sebesar 2,359. Simpulan: ada hubungan antara umur, pendidikan, pekerjaan, paritas, jarak kelahiran ibu hamil dengan kejadian KEK.
\end{abstract}

Kata kunci: Maternal Faktor, KEK, Ibu Hamil

\section{Maternal Factors Related to The Event of Less Chronic Energy (KEK) in Pregnant Women in Urban Area}

\begin{abstract}
Introduction:The 2015 Indonesian health profile shows that the maternal mortality rate (MMR) is 305 maternal deaths per 100,000 live births. The complications that occur are of course inseparable from the poor nutritional status of the mother and ultimately have an impact on the condition of the fetus being born (Ministry of Health, Republicof Indonesia, 2015). Method:The research used is an observational study with a case control approach. The population in this study were all pregnant women from 1 sd 12, 2017. Case criteria are all suspected pregnant women with $K E K$ recorded in the pregnancy register book and LILA examinatios known less than $23,5 \mathrm{~cm}$. Data analysis: univariate analysis, bivariate analysis, multivariate analysis. Results: of the research of pregnant women obtained a frequency distribution based on the incidence of KEK as many as 87 cases of KEK. The results of the analysis of the relationship between the age and the incidence of KEK obtained a significant value of $p=0.007$ OR obtained at 3.302. Analysis of the relationship between the education with the incidence of KEK obtained a significant value of $p=0.030$ OR obtained at 1.870. Analysis of the relationship between the occupation and the incidence of KEK obtained a significant value of $p=0.002$ OR was obtained for 2.538. Analysis of the relationship between parity and the incidence of KEK obtained a significant value of $p=0.000$ OR obtained at 2.758. Analysis of the relationship between birth spacing and the incidence of KEK obtained a significant value of $p=0.014$ OR obtained at 2.359. Conclusion: In conclusion there is a relationship between age, education, occupation, parity, birth spacing of pregnant women and incidence of KEK.
\end{abstract}

Key words: Maternal Factor, KEK, Pregnant 


\section{PENDAHULUAN}

Menurut Departemen Kesehatan RI tahun 2010, penyebab langsung kematian ibu adalah perdarahan $(28 \%)$, eklampsia $(24 \%)$ dan infeksi (11\%). Penyebab tidak langsung kematian ibu antara lain kurang energi kronis (KEK) pada kehamilan (37\%) dan anemia pada kehamilan (40\%).

Profil kesehatan Indonesian tahun 2015 menunjukkan bahwa angka kematian ibu (AKI) adalah sebesar 305 kematian ibu per 100.000 kelahiran hidup. Ibu meninggal akibat dari komplikasi pada masa kehamilan, persalinan dan nifas. Komplikasi yang terjadi tentunya tidak terlepas dari buruknya status gizi ibu dan pada akhirnya berdampak kepada kondisi janin yang dilahirkan.

KEK adalah penyebabnya dari ketidakseimbangan antara asupan untuk pemenuhan kebutuhan dan pengeluaran energi. Kekurangan Energi Kronis (KEK) adalah keadaan dimana remaja putri/wanita mengalami kekurangan gizi (kalori dan protein) yang berlangsung lama atau menahun. Kekurangan energi kronik (KEK) merupakan kondisi yang disebabkan karena adanya ketidakseimbangan asupan gizi antara energi dan protein, sehingga zat gizi yang dibutuhkan tubuh tidak tercukupi. Ibu hamil yang menderita KEK mempunyai resiko kematian ibu mendadak pada masa perinatal atau resiko melahirkan bayi dengan berat bayi lahir rendah (BBLR). Berdasarkan data Departemen Kesehatan RI tahun 2013, sekitar 146.000 bayi usia 0-1 tahun dan 86.000 bayi baru lahir $(0-28$ hari) meninggal setiap tahun di Indonesia. Angka kematian bayi adalah 32/1000 Kelahiran Hidup, lima puluh empat persen penyebab kematian bayi adalah latar belakang gizi.

Berdasarkan penelitian yang dilakukan oleh Handayani, Sri dan Budianingrum, Suci (2011) dengan judul Analisis Faktor Yang Mempengaruhi Kekurangan Energi Kronis Pada lbu Hamil di Wilayah Puskesmas Wedi Klaten, didapatkan dari uji logistic ganda diperoleh hasil jarak kelahiran $P=0,999$, pendidikan $P=0,020$, pengetahuan $P=0,014$. Berdasarkan hasil analisis jarak kelahiran, pendidikan dan pengetahuan dapat memprediksi kejadian KEK pada ibu hamil.

Berdasarkan penelitian yang dilakukan oleh Fathamira Hamzah Diza (2017) dengan judul Analisis Faktor Yang Memengaruhi
Kejadian Kekurangan Energi Kronis (KEK) Pada lbu Hamil Di Wilayah Kerja Puskesmas Kota Langsa Provinsi Aceh Tahun 2016, didapatkan hasil pendapatan ibu hamil yang tergolong dibawah upah minimum provinsi Aceh tahun 2016 merupakan variabel independen yang paling berpengaruh untuk mengalami KEK pada ibu hamil $P=0,208$.

Menurut data rekam medik yang diperoleh dari Bidan Praktik Mandiri Ellna pada tahun 2015 ibu yang melakukan pemeriksaan kehamilan sebanyak 1.732 ibu dan yang mengalami KEK sebanyak $70 \mathrm{ibu}$, pada tahun 2016 ibu yang melakukan pemeriksaan kehamilan sebanyak 1.550 ibu dan yang mengalami KEK sebanyak $50 \mathrm{ibu}$ dan pada tahun 2017 ibu yang melakukan pemeriksaan kehamilan sebanyak 1.620 dan ibu yang mengalami KEK sebanyak 35 ibu.

Berdasarkan latar belakang diatas maka penulis tertarik untuk melakukan penelitian tentang "Faktor Maternal Yang Berhubungan Dengan Kejadian Pada Ibu Hamil Di Daerah Urban".

\section{BAHAN DAN METODE}

Desain Penelitian: Rancangan penelitian yang digunakan penelitian observasional dengan pendekatan case control. Lokasi Penelitian: Jalan Ali Gatmir 11 Ilir no. 105 RT.04 RW.01 Palembang. Populasi dan Sampel: Populasi dalam penelitian ini adalah semua ibu hamil di Bidan Praktik Mandiri Ellna Palembang pada bulan Januari sd Desember tahun 2017. Kriteria Kasus adalah semua tersangka ibu hamil dengan KEK yang tercatat dalam buku register kehamilan dari bulan Januari sampai dengan Desember tahun 2017 dan pemeriksaan LILA diketahui kurang dari $23,5 \mathrm{~cm}$ dan bertempat tinggal di wilayah urban. Kriteria Kontrol adalah semua tersangka ibu hamil yang tidak KEK yang tercatat dalam buku register kehamilan dari bulan Januari sampai dengan Desember tahun 2017 dan pada pemerikaan LILA $\geq 23,5$ $\mathrm{cm}$ dan bertempat tinggal diwilayah urban.

Teknik pengumpulan data: Data sekunder adalah data yang didapat tidak secara langsung dari objek penelitian (Arikunto, Suharsimi, 2010). Data yang dikumpulkan merupakan data sekunder yang diperoleh melalui observasi rekam medik pasien ibu hamil dengan KEK dari bulan Januari sampai dengan bulan Desember di 
BPM Ellna Tahun 2017.Teknik Analisa Data: Analisis univariat Digunakan untuk menggambarkan variabel-variabel deskriptif seperti umur, pendidikan, pekerjaan, jarak kelahiran, paritas dengan KEK di Bidan Praktik Mandiri Ellna Palembang. Analisis bivariat: Untuk melihat hubungan masingmasing variabel independen terhadap variable dependent dengan menggunakan uji ChiSquare nilai a 0,05 untuk menganalisis hubungan antara variabel independen (umur, pendidikan, pekerjaan, jarak kelahiran, paritas) dengan KEK jika $p$ value $\leq 0,05$ maka hasil perhitungan secara statistik bermakna jika $p$ value $>0,05$ maka hasil perhitungan statistik tidak bermakna. Analisa Multivariat: Pada analisa multivariat peneliti menggunakan uji statistik regresi logistik karena metoda ini dianggap cocok untuk menjelaskan penelitian dengan variabel dependen (Y) numerik dan variabel independen (X) maupun katagorik, melalui beberapa langkah sampai pada model hasil akhir.

\section{HASIL}

\section{Analisa Univariat}

Tabel 1

Karakteristik Responden

\begin{tabular}{lcc}
\hline Variabel & Jumlah & Persen (\%) \\
\hline $\begin{array}{l}\text { Kejadian KEK } \\
\text { Ya }\end{array}$ & 87 & 33,3 \\
Tidak & 174 & 66,7 \\
\hline $\begin{array}{l}\text { Umur } \\
<=20->35 \\
\text { tahun }\end{array}$ & 215 & \\
\hline $20-35$ tahun & 46 & 82,4 \\
\hline $\begin{array}{l}\text { Pekerjaan } \\
\text { Tidak bekerja }\end{array}$ & 166 & 17,6 \\
\hline Bekerja & 95 & 63,6 \\
\hline Pendidikan & & 36,4 \\
< SMA & 89 & 34,1 \\
\hline$>=$ SMA & 172 & 65,9 \\
\hline Paritas & Jumlah & Persen (\%) \\
\hline $\begin{array}{l}\text { Paritas } \\
\text { Resiko tinggi }\end{array}$ & 86 & 33,0 \\
\hline Resiko rendah & 175 & 67,0 \\
\hline Resiko tinggi & 46 & 17,6 \\
\hline Resiko rendah & 215 & 82,4 \\
\hline
\end{tabular}

\section{Distribusi Berdasarkan Umur}

Tabel 1 menunjukkan distribusi frekuensi berdasarkan umur sebanyak 215 $(82,4 \%)$ Ibu hamil berusia beresiko $(<=20->$ 35 tahun) lebih banyak dibandingkan dengan usia tidak beresiko (20-35 tahun) sebanyak 46 $(17,6 \%)$. Distribusi frekuensi berdasarkan pekerjaan Ibu hamil yang tidak bekerja sebanyak $166 \quad(63,6 \%)$ lebih banyak dibandingkan dengan lbu hamil yang bekerja yaitu 95 (36,4\%). Distribusi frekuensi berdasarkan pendidikan. Ibu hamil yang mempunyai pendidikan < SMA sebanyak 89 $(34,1 \%)$ sedangkan lbu hamil yang mempunyai pendidikan $\geq$ SMA yaitu 172 (65,9\%). Distribusi frekuensi berdasarkan paritas. Ibu hamil yang dengan paritas resiko tinggi sebanyak 86 (33\%) sedangkan lbu hamil dengan paritas resiko rendah yaitu 175 (67\%). istribusi frekuensi berdasarkan jarak kehamilan. Ibu hamil yang dengan jarak kehamilan resiko tinggi sebanyak $46(17,6 \%)$ sedangkan Ibu hamil dengan jarak kehamilan resiko rendah yaitu $215(82,4 \%)$.

\section{Analisis Bivariat}

Tabel 2. menunjukkan bahwa hubungan umur dengan Kejadian KEK umur berisiko 
pada kasus sebesar 92\% lebih besar dibandingkan kontrol yaitu sebesar $77,6 \%$. Hasil analisis hubungan antara umur ibu hamil dengan kejadian KEK menggunakan Uji Chi Square, diperoleh nilai signifikan $p=0,007$ ( $p$ value $<0,05)$. Hal ini menunjukkan bahwa terdapat hubungan antara umur ibu hamil dengan atau OR $>1$, hal ini menunjukkan bahwa ibu hamil dengan kejadian KEK ibu hamil dengan Odds Ratio diperoleh sebesar 3,302 atau OR > 1, hal ini menunjukkan bahwa ibu hamil dengan umur tidak beresiko.

Tabel 2

Hasi Uji Bivariat

\begin{tabular}{|c|c|c|c|c|c|}
\hline \multirow[t]{2}{*}{ Variabel } & \multicolumn{2}{|c|}{ Kejadian KEK } & \multirow[b]{2}{*}{$\begin{array}{l}\text { Total } \\
\text { n (\%) }\end{array}$} & \multirow[b]{2}{*}{$p$ value } & \multirow[b]{2}{*}{$\begin{array}{c}\text { OR } \\
(95 \% \mathrm{Cl})\end{array}$} \\
\hline & $\begin{array}{c}\text { Ya } \\
\text { n (\%) }\end{array}$ & $\begin{array}{l}\text { Tidak } \\
\text { n (\%) }\end{array}$ & & & \\
\hline \multicolumn{6}{|l|}{ Usia } \\
\hline $\begin{array}{l}<=20->35 \\
\text { thn } \\
20-35 \text { thn }\end{array}$ & $\begin{array}{c}80(92,0) \\
7(8,0)\end{array}$ & $\begin{array}{c}135(77,6) \\
39(22,4)\end{array}$ & $\begin{array}{c}215(82,4) \\
46(17,6)\end{array}$ & 0,007 & $\begin{array}{c}3,302 \\
(1,410- \\
7,730)\end{array}$ \\
\hline \multicolumn{6}{|l|}{ Pendidikan } \\
\hline$<$ SMA & $\begin{array}{c}38 \\
(43,7)\end{array}$ & $51(29,2)$ & $89(34,1)$ & \multirow[t]{2}{*}{0,030} & $\begin{array}{c}1,870 \\
(1,096- \\
3,193)\end{array}$ \\
\hline$>=\mathrm{SMA}$ & $\begin{array}{c}49 \\
(56,3)\end{array}$ & $123(70,7)$ & $172(65,9)$ & & \\
\hline \multicolumn{6}{|l|}{ Pekerjaan } \\
\hline Tidak bekerja & $67(77,0)$ & $99(56,9)$ & $166(63,6)$ & \multirow[t]{2}{*}{0,002} & $\begin{array}{c}2,538 \\
(1,417- \\
4,545)\end{array}$ \\
\hline Bekerja & $20(23,0)$ & $75(43,1)$ & $95(36,4)$ & & \\
\hline \multicolumn{6}{|l|}{ Paritas } \\
\hline Resiko tinggi & $42(48,3)$ & $44(25,3)$ & $86(33,0)$ & \multirow[t]{2}{*}{0,000} & \multirow[t]{2}{*}{$\begin{array}{l}2,758 \\
(1,604- \\
4,741)\end{array}$} \\
\hline $\begin{array}{l}\text { Resiko } \\
\text { rendah }\end{array}$ & $45(51,7)$ & $130(74,7)$ & $175(67,0)$ & & \\
\hline \multicolumn{6}{|l|}{$\begin{array}{l}\text { Jarak } \\
\text { Kelahiran }\end{array}$} \\
\hline Resiko tinggi & $23(26,4)$ & $23(13,2)$ & $46(17,6)$ & \multirow[t]{2}{*}{0,014} & \multirow[t]{2}{*}{$\begin{array}{l}2,359 \\
(1,235- \\
4,509)\end{array}$} \\
\hline $\begin{array}{l}\text { Resiko } \\
\text { rendah }\end{array}$ & $64(73,6)$ & $151(86,8)$ & $215(82,4)$ & & \\
\hline
\end{tabular}

Untuk pendidikan < SMA pada kasus sebesar 43,7\% lebih besar dibandingkan kontrol yaitu sebesar 29,2\%. Hasil analisis hubungan antara pendidikan ibu hamil dengan kejadian KEK menggunakan Uji Chi Square, diperoleh nilai signifikan $p=0,030$ ( $p$ value $<0,05$ ). Hal ini menunjukkan bahwa terdapat hubungan antara pendidikan lbu hamil dengan kejadian KEK pada lbu hamil dengan Odds Ratio diperoleh sebesar 1,870 atau OR $>1$, hal ini menunjukkan bahwa ibu hamil dengan pendidikan < SMA memiliki risiko 1,870 kali mengalami kekurangan energi kronik dibanding ibu hamil dengan pendidikan $\geq$ SMA.

Pada variabel pekerjaan dapat diketahui bahwa lbu hamil yang tidak bekerja pada kasus sebesar $77 \%$ lebih besar dibandingkan kontrol yaitu sebesar $56,9 \%$. Hasil analisis hubungan antara pendidikan ibu hamil dengan kejadian KEK menggunakan Uji Chi Square, diperoleh nilai signifikan $\mathrm{p}=0,002$ ( $p$ value $<$ 
0,05). Hal ini menunjukkan bahwa Ho ditolak dan $\mathrm{Ha}$ diterima sehingga dapat disimpulkan terdapat hubungan antara pekerjaan Ibu hamil dengan kejadian KEK pada Ibu hamil. Nilai perhitungan Odds Ratio diperoleh sebesar 2,538 atau OR $>1$, hal ini menunjukkan bahwa ibu hamil yang tidak bekerja memiliki risiko 2,538 kali mengalami kekurangan energi kronik dibanding ibu hamil yang bekerja. Untuk variabel paritas diketahui yang memiliki resiko tinggi pada kasus sebesar 48,3\% lebih besar dibandingkan kontrol yaitu sebesar 25,3\%,. Hasil analisis hubungan antara paritas dengan kejadian KEK menggunakan Uji Chi Square, diperoleh nilai signifikan $p=0,000$ ( $p$ value $<0,05$ ). Hal ini menunjukkan bahwa terdapat hubungan antara paritas Ibu hamil dengan kejadian KEK pada lbu hamil. Nilai perhitungan Odds Ratio diperoleh sebesar 2,758 atau OR $>1$, hal ini menunjukkan bahwa ibu hamil yang dengan paritas resiko tinggi memiliki risiko 2,758 kali mengalami kekurangan energi kronik dibanding ibu hamil dengan paritas resiko rendah.

Jarak kehamilan dari hasil analisis diketahui bahwa lbu hamil dengan jarak kelahiran resiko tinggi pada kasus sebesar 26,4\% lebih besar dibandingkan kontrol yaitu sebesar 13,2\%. Hasil analisis hubungan antara jarak kelahiran dengan kejadian KEK menggunakan Uji Chi Square, diperoleh nilai signifikan $p=0,014$ ( $p$ value $<0,05$ ). Hal ini menunjukkan bahwa terdapat hubungan antara jarak kehamilan lbu hamil dengan kejadian KEK pada lbu hamil. Nilai perhitungan Odds Ratio diperoleh sebesar 2,359 atau OR $>1$, hal ini menunjukkan bahwa ibu hamil yang dengan jarak kelahiran resiko tinggi memiliki risiko 2,359 kali mengalami kekurangan energi kronik dibanding ibu hamil dengan jarak kelahiran resiko rendah.

\section{Analisis Multivariat}

\section{Tabel}

Model Regresi Logistik Metode Enter

\begin{tabular}{lccccc}
\hline Variabel & Koefisien & p value & Exp (B) & \multicolumn{2}{c}{ 95\% Cl } \\
\cline { 5 - 6 } & & (Sig.) & & Lower & Upper \\
\hline Pekerjaan & $-4,036$ & 0,000 & 0,018 & 0,004 & 0,088 \\
Umur & $-2,175$ & 0,000 & 0,114 & 0,041 & 0,312 \\
Paritas & $-2,069$ & 0,000 & 0,126 & 0,049 & 0,325 \\
Jarak Kehamilan & $-2,703$ & 0,001 & 0,067 & 0,014 & 0,326 \\
\hline Constant = 15,339 & & & & &
\end{tabular}

Pada tabel di atas menunjukkan bahwa variabel yang dominan dalam kejadian KEK pada Ibu hamil yaitu usia ( $p$ value $=0,000$ ), pekerjaan ( $p$ value $=0,000)$, paritas $(p$ value $=$ $0,000)$ dan jarak kehamilan $(p$ value $=0,001)$.

\section{PEMBAHASAN}

\section{Hubungan Usia dengan Kejadian KEK}

Hasil penelitian menunjukkan bahwa terdapat hubungan antara umur ibu hamil dengan kejadian KEK pada Ibu hamil. Sejalan dengan penelitian Aeda Ernawati yang berjudul Hubungan Usia dan Status Pekerjaan Ibu Dengan Kejadian Kurang Energi Kronis Pada Ibu Hamil yang menyatakan bahwa umur ibu hamil digolongkan menjadi dua yaitu berisiko dan tidak berisiko. Umur berisiko maksudnya umur ibu hamil mempunyai risiko tinggi jika mengalami kehamilan yaitu umur terlalu muda ( $<20$ tahun) dan terlalu tua ( $>35$ tahun). Umur tidak berisiko maksudnya umur ibu yang dianjurkan untuk mengalami kehamilan yaitu usia 20-35 tahun.

Umur ibu merupakan salah satu faktor penting dalam proses kehamilan sampai persalinan. Hasil penelitian menunjukkan sebagian besar ibu hamil termasuk dalam kelompok usia reproduksi sehat yaitu usia 2035 tahun, baik pada kelompok ibu hamil yang mengalami KEK maupun kelompok ibu hamil yang tidak mengalami KEK. Hasil uji statistik diperoleh nilai $p=0,03$ dan nilai rasio prevalens sebesar 4,089. Artinya ibu yang usianya terlalu muda ( $<20$ tahun) atau terlalu tua $(>35$ 
tahun) berisiko mengalami KEK pada saat hamil sebesar 4,089 kali dibandingkan ibu hamil pada usia 20-35 tahun. Hal ini menunjukkan bahwa ada pengaruh usia ibu hamil terhadap kejadian KEK.

Proverawati \& Asfuah (2009), menyebutkan ibu yang mengalami kehamilan pada usia muda ( $<20$ tahun) atau usia tua ( $>$ 35 tahun) membutuhkan zat gizi yang lebih banyak dari pada ibu yang hamil pada saat usia reproduksi sehat (usia 20-35 tahun). Kehamilan yang terjadi pada usia muda menyebabkan terjadinya kompetisi pemenuhan zat gizi antara janin dan ibunya. Ibu yang hamil pada saat usia remaja atau kurang dari 20 tahun memerlukan zat gizi yang banyak untuk memenuhi kebutuhan gizi ibu dan janin yang sedang dikandungnya. $\mathrm{Hal}$ ini terjadi karena ibu masih dalam usia pertumbuhan. Pertumbuhan dan perkembangan yang pesat terjadi pada usia remaja. Usia kurang dari 20 tahun termasuk usia remaja.

Adapun ibu hamil yang berusia lebih dari 35 tahun memiliki organ tubuh yang fungsinya semakin melemah. Pengaruh proses penuaan juga mulai muncul. Kondisi ini ditandai adanya penyakit hipertensi dan diabetes mellitus yang dapat menghambat masuknya makanan bagi janin melalui plasenta. Oleh karena itu wanita yang hamil pada usia lebih dari 35 tahun memerlukan energi yang besar untuk mendukung kehamilannya.

Kehamilan di usia muda terjadi karena pernikahan dilakukan pada usia muda menyatakan bahwa dampak signifikan dari pernikahan usia muda adalah ibu muda tidak tahu atau tidak memahami masalah kehamilan. Ibu tidak memahami kebutuhan gizi bagi ibu hamil. Kondisi ini dapat menyebabkan anak yang dilahirkan menjadi kurang gizi yaitu bayi lahir dengan berat badan yang rendah (BBLR).

Sementara saat ini kehamilan di usia 35 tahun atau lebih cenderung meningkat. Kondisi ini kemungkinan disebabkan semakin berkembangnya bidang pendidikan dan lapangan kerja bagi kaum wanita. Wanita yang berpendidikan tinggi berupaya mencari kerja untuk mengaktualisasikan diri. Akhirnya banyak wanita yang terlambat untuk berkeluarga :
Menurut peneliti ibu hamil dengan usia < 20 tahun dan > 35 tahun harus rutin memeriksakan kehamilannya terutama konsultasi pada ahli gizi agar banyak mendapat pengetahuan tentang makanan yang bergizi dan bagaimana cara mengelolah makanan yang baik dan benar supaya kandungan gizi dalam makanan tetap terjamin kualitasnya.

\section{Hubungan Pendidikan dengan Kejadian KEK}

Hasil penelitian di atas menunjukkan bahwa terdapat hubungan pendidikan dengan kejadian KEK. Sejalan dengan penelitian Anggiani Nurhasna Furqi (2016), dengan judul Faktor-Faktor yang Berhubungan Dengan Kejadian Kekurangan Energi Kronik (KEK) Pada Ibu Hamil di Puskesmas Halmahera Semarang. Menyatakan berdasarkan hasil yang dapat diketahui bahwa jumlah ibu hamil yang memiliki pendidikan terakhir tidak lulus SD / SD / SMP pada kasus sebesar $60 \%$ lebih besar dibandingkan kontrol sebesar $13,3 \%$. Sedangkan ibu hamil yang memiliki pendidikan terakhir SMA/PT pada kasus sebesar $40 \%$ lebih kecil dibandingkan pada kontrol sebesar 86,7 \%. Dari Uji Chi Square, diperoleh nilai signifikan $p=0,0001$ (p.value < $0,05)$. Hal tersebut menunjukkan bahwa Ho (hipotesis nihil) ditolak dan $\mathrm{Ha}$ (hipotesis alternatif) diterima sehingga terdapat hubungan antara pendidikan ibu hamil dengan kejadian KEK. Dari perhitungan Odds Ratio diperoleh nilai OR sebesar 9,75 atau OR $>1$, hal ini menunjukkan bahwa ibu hamil dengan pendidikan tidak tamat SD/SD/SMP memiliki risiko 9,75 kali mengalami kekurangan energi kronik dibanding ibu hamil dengan pendidikan tamat SMA/PT.

Pendidikan merupakan salah satu ukuran yang digunakan dalam status sosial ekonomi. Pendidikan merupakan hal utama dalam peningkatan sumber daya manusia. Pendidikan juga merupakan gejala universal pada manusia yang didalamnya terdapat nilainilai untuk di integrasikan dalam realitas kehidupan sosial kemasyarkatan, karena pendidikan sebagai proses pemanusiaan manusia, maka keberlangsungan pendidikan harus di dukung oleh semua komponen yang ada agar pendidikan menjadi suatu alat komunikasi. 
Menurut peneliti pendidikan merupakan hal yang sangat penting dalam hal berkomunikasi atau dalam menyampaikan suatu pesan. Dengan pendidikan tinggi minimal SMA akan membantu seseorang untuk menyerap dan memahami tentang pengetahuan makanan yang bergizi yang penting untuk tubuh terutama selama kehamilan untuk menghindari terjadinya KEK.

\section{Hubungan Pekerjaan dengan Kejadian KEK}

Hasil penelitian menunjukkan bahwa terdapat hubungan antara pekerjaan Ibu hamil dengan kejadian KEK pada Ibu hamil. Sejalan dengan penelitian Aeda Ernawati yang berjudul Hubungan Usia dan Status Pekerjaan Ibu Dengan Kejadian Kurang Energi Kronis Pada lbu Hamil dengan hasil yang menyatakan ibu hamil yang mengalami KEK di Puskesmas Gabus 1 Kabupaten Pati sebagian besar terdapat pada kelompok ibu yang tidak bekerja atau beraktivitas sebagai ibu rumah tangga. Hasil uji statistik diperoleh nilai $p=0,012$ dan nilai Rasio prevalens sebesar 9,286. Artinya ibu hamil yang tidak bekerja berisiko mengalami KEK sebesar 9,286 kali dibandingkan ibu hamil yang bekerja.

Perempuan yang bekerja memiliki kemampuan mengambil keputusan untuk mengatasi masalah kesehatan yang dihadapi. Oleh karena itu wanita yang berperan sebagai pekerja sekaligus sebagai seorang istri dan ibu rumah tangga umumnya memiliki kesehatan yang lebih baik. Seseorang yang bekerja dapat meningkatkan pengetahuan karena pengalaman dan pergaulan serta dan interaksi sosial yang luas.

Menurut peneliti ibu yang bekerja dan mempunyai penghasilan akan lebih mudah dalam meningkatkan gizinya. Karena dengan bekerja ibu dapat membantu perekonomian dalam keluarga. Dan dengan bekerja serta mempunyai penghasilan ibu dapat mampu mengambil keputusan untuk mengatasi masalah kesehatannya.

\section{Hubungan Paritas dengan Kejadian KEK}

Hasil penelitian menunjukkan bahwa terdapat hubungan antara paritas Ibu hamil dengan kejadian KEK pada lbu hamil. Sejalan dengan penelitian Laila Rahmi juga menyatakan bahwa terdapat hubungan paritas dengan KEK pada ibu hamil di
Puskesmas. Paritas adalah status seorang wanita sehubungan dengan jumlah anak yang pernah dilahirkan. Paritas yang termasuk dalam faktor resiko tinggi dalam kehamilan adalah grademultipara, dimana hal ini dapat menimbulkan keadaan mempengaruhi optimalisasi ibu maupun janin pada kehamilan yang dihadapi. Dapat disimpulkan kalau paritas yang tidak lebih dari 4 tidak berisiko mengalami gangguan. Hasil penelitian Albugis D (2008), menunjukkan bahwa ibu hamil yang mempunyai paritas lebih dari 4 orang lebih berisiko KEK dibandingkan dengan ibu yang mempunyai paritas kurang dari 4 orang.

Menurut asumsi peneliti ibu yang memiliki anak lebih dari 4 akan mempengaruhi perekonomian dalam keluarga. Dimana kebutuhan yang diperlukan meningkat dengan tidak seimbangnya penghasilan yang didapat sehingga menyebabkan ibu kekurangan gizi karena kesulitan untuk mengkonumsi makanan yang bergizi. Dimana tubuh ibu memerlukan zat besi dan makanan yang bergizi lainya.

\section{Hubungan Jarak Kelahiran dengan Kejadian KEK}

Hasil penelitian menunjukkan bahwa terdapat hubungan antara jarak kehamilan Ibu hamil dengan kejadian KEK pada Ibu hamil. Sejalan dengan penelitian Sri Handayani , Suci Budianingrum dengan judul Analisis Faktor Yang Mempengaruhi Kekurangan Energi Kronis Pada lbu Hamil di Wilayah Puskesmas Wedi Klaten. Dengan hasil bahwa Pengaruh Jarak Kelahiran terhadap Kejadian KEK hasil penelitian diperoleh nilai $p=0,047$, Berdasarkan hasil analisis multivariat dengan uji analisis regresi logistik ganda diperoleh hasil jarak kelahiran $(p=0,999)$, hal ini menunjukkan bahwa ada pengaruh antara jarak kelahiran terhadap kejadian KEK.

Jarak melahirkan yang terlalu dekat $(<2$ tahun) akan menyebabkan kualitas janin atau anak yang rendah dan juga akan merugikan kesehatan ibu. Jarak melahirkan yang terlalu dekat akan menyebabkan ibu tidak memperoleh kesempatan untuk memperbaiki tubuhnya sendiri dimana ibu memerlukan energi yang cukup untuk memulihkan keadaan setelah melahirkan anaknya. Ibu juga masih dalam masa menyusui dan harus memenuhi kebutuhan gizi selama menyusui, dimana saat menyusui ibu membutuhkan 
tambahan kalori setiap hari untuk memenuhi gizinya dan produksi, dengan hamil kembali maka akan menimbulkan masalah gizi ibu dan janin atau bayi berikut yang dikandung.

Menurut peneliti bahwa jarak kelahiran dapat mempengaruhi kesehatan janin maupun ibu. Jika kurang dari dua tahun maka bisa berdampak buruk bagi kesehatan ibu dan janin. Pengaruhnya pada kesehatan ibu adalah meningkatkan risiko perdarahan dan kematian saat melahirkan, ibu juga tidak dapat memberikan ASI eksklusif pada anak. Dan risiko yang terjadi pada janin yaitu kelahiran mati atau kecacatan, berat badan lahir rendah dan kelahiran prematur.

\section{SIMPULAN DAN SARAN Simpulan}

Berdasarkan hasil penelitian yang telah dilakukan dapat disimpulkan bahwa ada hubungan antara umur ibu hamil dengan kejadian KEK dengan nilai signifikan. Ada hubungan antara pedidikan ibu hamil dengan kejadian KEK dengan nilai signifikan. Ada hubungan pekerjaan dengan kejadian KEK dengan nilai signifikan. Ada hubungan paritas dengan kejadian KEK dengan nilai signifikan. Ada hubungan jarak kelahiran dengan kejadian KEK dengan nilai signifikan.

\section{Saran}

Bagi Ibu Hamil: Diharapkan bagi ibu hamil untuk rutin memeriksakan kehamilannya minimal 4 kali selama kehamilan. Supaya dapat diketahui secara dini dan penanganan segera apa bila terdapat kelainan dan komplikasi pada kehamilannya. Bagi BPM Ellna: Diharapkan dapat menjadi sumber informasi bagi BPM Ellna Palembang dalam upaya meningkatkan pelayanan kesehatan pada ibu hamil

\section{KEPUSTAKAAN}

Departemen Kesehatan RI. 2010. Pemantauan Wilayah Setempat. Diunduh tanggal 8 Desember 2013 dari http:// www. Gizikia. Depkes. Go.id/ wp. Content/Pedoman-PWS-KIA.

Kementerian Kesehatan RI. 2015. Profil Kesehatan Indonesia Tahun 2015 dalam http://www.Depkes go.id/ resurces/download/pusdatin/ profilkesehatan-Indonesia/ Profilkesehatan-
Indonesia-2015.pdf diakses tanggal 19 Oktober 2017 pukul 10.45 wib

Departemen Gizi dan Kesmas FKMUI. 2009. Penanganan KEK. Jakarta. Universitas Indonesia.

Departemen Kesehatan RI. 2013. Angka Kematian Ibu dan Bayi. Jakarta: Badan Penelitian dan Pengembangan Kesehatan Kemenkes RI.

Handayani, Sri dan Budianingrum, Suci. 2011. Analisis Faktor Yang Mempengaruhi Kekurangan Energi Kronis Pada Ibu Hamil di Wilayah Puskesmas Wedi Klaten. Jurnal Involusi Kebidanan Vol 1 No 1.

Fathamira Hamzah Diza. 2016. Analisis Faktor Yang Memengaruhi Kejadian Kekurangan Energi Kronis (KEK) Pada Ibu Hamil Di Wilayah Kerja Puskesmas Kota Langsa Provinsi Aceh. Universitas Sains Cut Nyak Dhien Langsa. Jurnal Jumantik Volume 2 Nomer 2.

BPM Ellna Palembang tahun 2017

Ernawati Aeda. 2018. Hubungan Usia dan Status Pekerjaan Ibu Dengan Kejadian Kurang Energi Kronis Pada Ibu Hamil. Jurnal Litbang Vol. XIV, No.1 Juni : 2737.

Atika Proverawati dan Siti Asfuah. 2009. Buku Ajar Gizi Untuk Kebidanan. Yogyakarta. Nuha medika.

Mahirawati VK. 2014. Faktor-Faktor Yang Berhubungan Dengan Kekurangan Energi Kronis Pada lbu Hamil Di Kecamatan Kamoning dan Tambelangan, Kabupaten Sampang, Jawa Timur. Buletin Penelitian Sistem Kesehatan. Jakarta. Litbang Kesehatan.

Notoatmodjo, S. (2011). Kesehatan. Masyarakat IImu \& Seni. Jakarta: Rineka Cipta

Kristiyanasari,W. (2010). Gizi lbu Hamil. Yogyakarta: Nuha Medika.

Djamilah \& Kartikawati, R. (2014). Dampak Perkawinan Anak di Indonesia. JURNAL STUDI PEMUDA, 3(1), 1-16.

Pontoh, V. Y. Y., Tendean, H. M. M., Suparman, E. (2015). Profil Persalinan pada Usia $\geq 35$ Tahun di RSUP Prof. Dr. $R$. D. Kandou Manado. Jurnal e-Clinic (eCl), 3(3) 
Anggiani Nurhasna Furqi. 2016. Faktor-Faktor yang Berhubungan Dengan Kejadian Kekurangan Energi Kronik (KEK) Pada lbu Hamil di Puskesmas Halmahera Semarang.

Timmreck C. 2005. Epidemiologi Suatu Pengantar, Pekerjaan dan Pendidikan Sebagai Karakteristik Orang. Jakarta: Penerbit Buku Kedokteran. EGC. HIm 306-17.

Notoatmodjo, S. 2007. Kesehatan Masyarakat IImu dan Seni. Jakarta: Rineka Cipta. HIm 98-106.

Rahmi Laila. Faktor-faktor yang berhubungan dengan kekurangan energi kronik (kek) pada ibu hamil di puskesmas belimbing padang. Jurnal kesehatan medika saintika Volome 8 Nomor 1 | http:// jurnal.syedzasaintika.ac.id. e-ISSN: 2540-961, p-ISSN: 2087-8508.
Yunus M. Firdaus. 2004. Pendidikan Berbasis Raelitas Sosial. Yogjakarta: Logung Pustaka. HIm 7-11.

Najoan, J., Manampiring, A. (2011). Hubungan Kurang Tingkat Sosial Ekonomi dengan Kurang Energi Kronik pada lbu Hamil di Kelurahan Krombos Barat Kecamatan Singkil Kota Manado.: Universitas Sam Ratulang

Manuaba. 2010. Ilmu Kebidanan, Penyakit Kandungan dan Keluarga Berencana Untuk Pendidikan Bidan. Jakarta: EGC.

Albugis D. 2008. Faktor-Faktor Yang Mempengaruhi Berat Bayi lahir. Penelitian. Jakarta.

Baliwati, Yayuk Farida. 2004. Pengantar Pangan dan Gizi. Jakarta. Penebar Swadaya. 